\title{
Dancing with Myriam: Creating and Staging a New Metaphor for the Process of Translation
}

\author{
Paula Pratt \\ Coppin State University, U. S. A. \\ "[There exists] the capacity of metaphor ... \\ to yield some true insight about reality." \\ Paul Ricoeur \\ "In all too many cases the metaphors do not... \\ provide much in the way of fresh insights." \\ James St. André
}

\section{Introduction}

Since first coming across Susan Bassnett's preface to the 1991 revised edition of Translation Studies, I've collected metaphors for the translation process. The analogy that fascinated me, and aroused my curiosity about this sort of critical activity, was this: "Brazilian translators have introduced a new metaphor, one that may be applicable to this new alternative perspective on translating - the image of the translator as cannibal, devouring the source text in a ritual that results in the creation of something completely new" (xiv). Not all metaphors I've discovered are this graphic, but several are equally fascinating and enlightening.

When I read Bassnett's book for the first time in 2005, I was immersed in a project which had at its heart Nuala Ni Dhomhnaill's poem "The Language Issue" (155). I was teaching World Literature in Morocco, surrounded by speakers of several languages, constantly aware of translation, whether attempting to converse in Arabic, or while teaching texts translated into English. While discussing the poem with a World Literature class, I first thought I sensed a metaphor for the translation process within Ni Dhomhnaill's poem. Years later, when I read James St. André's "Translation and Metaphor: Setting the Terms," I saw how fortunate it was that I had not pursued that initial comparison. St. André's comments on the "multitude of metaphors for translation" which had appeared within a particular collection of essays: "in only one or two cases were these metaphors developed systematically; in all other cases they were single-sentence or, at most, singleparagraph ideas raised only then to be immediately abandoned. Such use of metaphors does little to advance our knowledge of translation. .." (3). Over those ensuing ten years, I worked to develop a script for what I now call "a staged metaphor." A first version was staged in Morocco in July, 2007, for an audience of students and faculty, most of whom contributed critical feedback. When I began

${ }^{1}$ All subsequent references to the poem are taken from this page. 
a revision a few years ago, I had not read St. André's rather strict dictum; however, I do believe that I have "developed [the metaphor] systematically" and that its performance will indeed "advance [the] knowledge of translation" if ever so slightly.

The Back Story (or, as in Irish storytelling, the short tale before the long one)

Between 1990 and 1992 I conducted research into the writing of some poets who had been in the vanguard of the emergence of Irish women's poetry in the 1980s. This work culminated in my doctoral dissertation, Even As We Speak: Heuristic Inquiry and the Staging of Contemporary Irish Women's Poetry. The women were writing at a time when they were just beginning to emerge onto the poetry scene in Ireland, after being virtually invisible for centuries. It wasn't that they hadn't written, but that they had not, for the most part, been published. This had begun to change in the late 1960s with the publication of the work of a few women, foremost among them Eavan Boland. It was from the work of these women that I had ultimately chosen twenty-seven poems to be included in my dissertation project.

The "staging" mentioned in the dissertation's title was that of a readers' theatre production, Sisters Be Damned, in which six women read the twenty-seven poems, each speaking as one of six "named voices." The Anchor sits in her kitchen, and listens to the marginalized voices represented in the poems, read by The Scholar, The Young Mother, The Fringe-Dweller, The Writer, and The Blasphemer. These motifs were ones that I had identified through a heuristic research process, ${ }^{2}$ grouping the poems they spoke, under the general theme of "women writing in a theocratic society." 3 The readers' theatre production, and the accompanying dissertation, had drawn me into the somewhat risky territory mapped by oral interpretation theorists Judith Espanola, Ronald Pelias and Jacquelyn Taylor, all of whom had discussed the use of the performance of literary texts as a means of doing literary criticism. I found support for my use of dramatic performance to interpret and critique literary texts in Espanola's description of this process as "publication" (90), and of Taylor's discussion of "performance knowledge [through which] the performer both reflects and clarifies the experience a silent reader has with [the] text" (76). This knowledge consists of the insights available to actors and directors alike, observations which Pelias claims are "neglected by other critical methods" (359).

My initial plan had been to retrieve critical feedback from the readers' theatre audience, and incorporate the suggestions into the process of creating a new script, in which the characters would be more defined, and there would be a more defined plot line. Most crucially, I would still use some of the poems as the basis of the women's conversations, relying on the critics' opinions as to which

\footnotetext{
${ }^{2}$ Used primarily in the social sciences, especially psychology, heuristic inquiry involves six phases. I adapted the final two phases, "explication" and "creative synthesis" as a tool for creating the six characters in the readers' theatre.

${ }^{3}$ In 1972 the Irish voted in a referendum to amend the Irish Constitution in order to remove the "special position" that had historically been granted to the Roman Catholic Church.
} 
poems might work best in that sort of production. I intended to do a "read through" of the new play and incorporate my analysis of that experience into my dissertation.

Fortunately, my dissertation committee advised me to work with what I had gleaned from the production of Sisters Be Damned, and use that knowledge to develop the new script in a future context. And so it was that I received my $\mathrm{PhD}$, and within four years found myself in Morocco, teaching in an English-language, U.S.-style school, Al Akhawayn University in Ifrane.

The Long Tale (in which North African women join the Irish, a paradigm shifts, the professor and her students read "The Language Issue," she remembers a "crib," and a new metaphor emerges).

In the spring of 2005, I was in my ninth year at AUI. I had built on my previous familiarity with creative drama to develop and use similar methods of teaching my literature classes, including the use of original, student-written dramas to critique the works they had read. As I shared my approach with colleagues, I sought to justify my method beyond the work of Taylor, Espinola and Pelias. It was at this time that one of those colleagues loaned me a copy of Susan Bassnett's Translation Studies, which provided new support for my continued use of drama as a critical medium. Bassnett describes the process of reading a printed text of a play as "incomplete. . since it is only in performance that the full potential of the text is realized" (Translation 120). Upon reading this, I began to see how her words could apply not only to the text of an original dramatic script, but also to literary texts in any genre. This was further enhanced as I read her quotation of Anne Ubersfeld's observation: "it is impossible to separate text from performance, since theatre consists of the dialectical relationship between both. .." (120). I realized, of course, that in the usual process of literary criticism, this "separation" of texts from their performance is not only probable, but also the norm. In the "real" academic world, performance of a literary text doesn't occur in the traditional process of literary criticism. Unusual as it may have seemed, my students were not only performing the texts, they were drawing on several texts and creating original mini-dramas which they then performed. Thus they came much closer to appreciating "the full potential of the text" (Bassnett, Translation 120).

After eight years in Morocco, I had moved further away from the growing number of new Irish women poets, and from the scholarship being done in that field. The AUI library had only begun to offer access to electronic databases, and I knew I would need to travel to Ireland to regain my scholarly footing. I therefore applied for a small University research grant, intending to resume work on the chamber theatre script after my research trip. I did receive the grant, but it carried the research committee's rather parochial stipulation that I include North African women's work in the project. Initially I was disappointed, since it seemed to suggest that I set aside my vision for the script. However, as I began to re-read some works of North African women, I could see that there would be little difficulty in maintaining my original theme, which was that of "women's work written within a theocratic culture." 
I had already become familiar with the work of Leila Abouzeid, whose novel, Year of the Elephant, had been the first work by a Moroccan woman to be translated from Arabic into English. I had also worked with my colleague, Michael Peyron, on his translation of poems by Mririda n-Ayt Attiq, a woman of the High Atlas Mountains, who had spoken her poems in Tachelhit. ${ }^{4}$ Finally, I had discovered L'Interdite/The Forbidden Woman, by Malika Mokeddem, an Algerian author. I thus saw the possibility of working with texts which represented the linguistic diversity of the region. I also had made the choice, early on, to limit myself to North African texts which had been translated into English, a decision which I realized would limit my choices. An additional challenge lay in the significant disparity between the number of North African women whose texts would be available in English, and that of the Irish women, most of whom wrote in English. Ultimately, I decided to limit the Irish women's works to those which had been written in Irish and translated into English. This would narrow the Irish field considerably, and align the number of texts more closely with that of the North African women.

At the same time, while I was reading the work of all these women, I came across an article by Marnia Lazreg, "Feminism and Difference: The Perils of Writing as a Woman on Women in Algeria." I was preparing a conference paper in which I was delineating the reasons for having grouped the women's work within the theme of "women writing in a theocratic society." In her essay, Lazreg discusses the "continuity between the traditional . . modes of apprehending North African and Middle-Eastern societies. One continuity, for example, is the predominance of a 'religious paradigm' that gives religion a privileged explanatory power ...' (83).

Although I had originally separated the Irish women's work according to which of the six characters ${ }^{5}$ would speak which poem, those categories were not especially religious or spiritual ones. It was only when I needed to incorporate the North African women that I looked again at the Irish women, seeking a connection to the new writers. I had rather quickly painted the two cultures (Irish Roman Catholic, and North African Muslim) with the broad brush of religion, and thereby named a connection and a unifying theme. After reading Lazreg's article, I concluded that, if I continued with that thematic focus, I would be reinforcing the place of religion as a dominant filter through which to view the writing of these women. For indeed, like the writing of scholars critiquing Middle East and North African women writers, the critical discourse surrounding the fledgling field of Irish women writers was replete with such examinations. I hoped that a new focus would take me down a more original creative path. I was already using a non-traditional research method (drama/performance as critique); thus, it seemed natural to view the work through a less-commonly used lens, the nature of which I had yet to decide.

\footnotetext{
4 One of the "Berber" dialects of North Africa; her poems had been translated into French in the 1920s, and Peyron, an expert speaker and scholar of Tachelhit, and a native speaker of French, translated them into English.

5 The Scholar, The Anchor, The Fringe Dweller, The Young Mother, The Writer, The Blasphemer.
} 
Ultimately a new paradigm emerged, undergirded by my own experience of living as a scholar in Morocco, teaching mostly translated texts to students for whom English was a second, third or even fourth language. Twice a week we met, and it was after one class, in which we had discussed Nuala Ni Dhomhnaill's "The Language Issue," that I experienced a certain focusing of the lens. In the poem ${ }^{7}$, the students had recognized the allusion to the story of Musa (the Arabic for Moses), and we had discussed the way in which the poet had used that tale to envision the journey of a text, as it issues forth from the poet out into the world. We had spoken about the mother of Musa, and the kind of hope she must have had for her infant, swaddled in a reed basket, as she let it go. We discussed what the poet suggests in the first lines, referring to her "hope . . in the little boat / of the language." They addressed questions: Who or what was represented by the Pharoah's daughter? Why did the poet end the poem with that scene? It was a particularly energized discussion, after which a student stopped and asked me about the rest of the story. I told her how Musa's sister suggests to the Pharaoh's daughter that she knows a Hebrew woman (meaning Musa's own mother) who could nurse the baby. Consequently, the infant was raised to childhood within his birth family, before being returned to Pharaoh's court. The two of us discussed how Ni Dhomhnaill had achieved her purpose by bringing the text to the reader in the image of the boat reaching the daughter, and that the rest of the Bible story (which was also in the Qur'an), was really not relevant to the analogy she had created. Our conversation ended, but my mind was racing with new possibilities.

Back in my office, I jotted down the thoughts and images that were coming to me. Repeatedly they were about Musa's sister, later identified in the Bible as "the prophet Myriam" (Exodus 15:20). These were the notes I typed when I reached my office:

Infant $=$ text

Pharaoh's daughter finds a baby, knows nothing about babies = a reader, receiving a text, cannot decipher it

Myriam = ??

Musa's (and Myriam's) mother = poet/author

Myriam brings infant to his mother; he grows into a child; she returns him to daughter.

Myriam takes the text to the author/poet; text is returned to daughter

Does Myriam = a translator?

Here, it seemed, was the new focus I had been seeking: the creative drama would be a metaphor, one version of how translation happens.

6 Translated by Paul Muldoon. His choice of "issue" rather than "question" when translating "ceist," foregrounds the additional meaning of the word, as referring to the "result" of a birth, i.e. the "issue" or infant. It is interesting that Walter Benjamin's statement, "translation issues from the original” (254), parallels Muldoon's double entendre.

7 This link takes the reader to a reading by Ni Dhomhnaill of her poem; text of the poem is seen beneath the video. https://www.youtube.com/watch?v=1c5lxRqzOEA 
A short time before that day, I had turned again to Bassnett's Translation Studies, in which I found several intriguing metaphors for the translation process. Paul Ricoeur speaks of "the capacity of metaphor to provide untranslatable information and, accordingly, . . . to yield some true insight about reality" (143). Metaphors for the process of translation, of which there have been many, have sought to "yield some true insight" as to how translation operates. Among those described by Bassnett are cannibalism, introduced by Brazilian translators (xiv), and Jacques Derrida's description of translation as "the breaking of the hymen, the penetration of the source text. .." (xv). There is, of course, the well- known "traduttore / traditore," (the translator is a traitor), and one which involves the translator's carrying the text across a bridge between two cultures (Ahlf-Wien). Bassnett's way of speaking about translation is aligned with that of "a number of women [who] in the $1980 \mathrm{~s}$. . began to discuss translation in figurative terms involving infidelity, unfaithfulness and reformed marriage." (xiii). One metaphor which I discovered more recently seems to emphasize the text's vulnerability: it is written beneath the title of an article by Ingo Schulze, in the parentheses which customarily hold the translator's name. Instead of "translated by" we read, "kidnapped from the German by Susan Bernofsky" (74).

While it might seem that the components of my story happened in sequence within a relatively brief time frame, the reality is that it all developed over several months. During that time I did take a trip to Ireland, in order to interview Ni Dhomhnaill, as well as Maire Mhac an $\mathrm{tSaoi}^{8}$, born in 1922, and the first poet to be published in Irish in Ireland. I wanted to learn what I could about their relationships, if any, with the persons who had translated their poems. It was during the interview with Mhac an tSaoi, that a memory surfaced from a statement of Ni Dhomhnaill's from several years before. In answer to my question about any relationship or collaboration with her translator(s), Mhac an tSaoi shook her head as if the idea of a translator was something extremely rare. She then admitted that she did not use translators, but did her own translating from her poems written in Irish. As she saw it, the "English versions" were not really poems, but "just cribs" (Interview).

It was that word "crib" which took me back to a 1990 poetry reading given by Nuala Ni Dhomhnaill. It was her custom to read the poems in both Irish and English, naming each translator. For one poem, however, she clarified that she had yet to give the Irish version to a translator. She explained: "Sure it's only a crib I've tossed off." The next day, when I had the opportunity to interview her, she explained further that the crib was written out in a hurry, just notes which had held the "sense of the Irish," until it could be translated into a "real poem, in English" (Interview). Sitting there in Maire Mhac an tSaoi's kitchen, hearing her reference her "cribs," and remembering NiDhomhnaill's comment from the earlier conversation, I first appreciated how central the image and metaphor of a crib would be for my drama work. That evening I made notes, which I later connected to the roots and meanings of the word crib:

8 Pronounced "whac-an-tee." 
The "boat / of the language" is compared to "a basket of intertwined / iris leaves," in which Moses's mother "put an infant."

This image of a basket with an infant overlays that of a baby's crib, so I need to check the various meanings and derivations of that word.

One meaning of "crib" is a short translation, done by the poet herself; like the crib/basket, it can hold the poem's initial form (its infancy) until it is handed on to a translator, who shares the translation with a broader world beyond that of its original (lexical) community.

Until that time, I had written only a few rough drafts of a script, but had not been able to envision the physical setting in which the action would take place. I had been stuck in readers' theatre mode, with little sense of how the women would interact with each other; what, exactly, would they do? When I had first thought of a chamber theatre production, I'd envisioned it in the kitchen of the woman known as The Anchor. Women would come and go from her house, seeking her wisdom and sharing their lives/words with each other. Once the drama had become a metaphor for the translation process, my challenge had been to design the movements and props through which that process would be enacted, while still retaining the story line of my original concept.

It was in the word "crib" that I found the concrete object that I needed. The crib is the "basket of intertwined / iris leaves" which carries the infant/text to the Pharaoh's daughter/reader. Metaphorically, it becomes the way in which a text, in a source language (SL) is handed off to, or connects with, a translator. For a poet such as NiDhomhnaill, it may often include the notes (cribs) that she makes in the target language (TL); for an author like Leila Abouzeid, it may involve occasional discussions or close work with the translator. Still other writers may choose to distance themselves from the translator completely. The metaphor which I developed and staged dramatizes one way in which some translators operate, by including the author in the process.

Thus, when Myriam makes good on her offer to enlist the poet's/mother's help, she takes the basket/text from the daughter and returns home. The physical basket/crib becomes the crucial fulcrum around which the dramatic action of the play revolves, and through which the process of translation will pass. In the process of writing the script, I researched the various derivations and meanings of this word ("crib"). What I found showed the very connection that I had intuited in that epiphanic moment outside the World Literature classroom. "Crib" derives from Middle English, French, and Old English, and is close to the Old High German "krippa," meaning "manger." A significant suggestion relates it to the Greek "griphos," meaning "a reed basket" (emphasis mine). Upon reading that, I imagined the melding of the "basket of intertwined / iris leaves" and the manger of Bethlehem. ${ }^{9}$ Other meanings are "a literal translation," and "a key to understanding a literary work," both of which supported Ni Dhomhnaill's and Mac an tSaoi's use of the word.

\footnotetext{
9 Irish tradition, I have been told, holds that the word "crib" was not used to describe a resting place for infants until
} after the Jesus narratives' depiction of his being "laid in a manger." 
Further layering, which enhanced the shaping of the metaphor, came from an examination of the Arabic words "mahd" (a direct Qur'anic root, ${ }^{10}$ used as a name for both boys and girls) and "mahida" (used as a girl's name, derived from Mahd). Both words mean "cradle" [crib], "place of comfort," and "starting point." Additionally, Mahida means "one who comforts," "one who makes things even and uniform," and "facilitator." This latter definition would assume more connotative significance in the revised script.

The play I put together that spring in Morocco had one staging, in July of 2007. At the end of the performance, I distributed questionnaires among audience members, some of whom were colleagues, and several of whom were translators. One of the most frequent comments was that there needed to be more movement, more interaction among the characters, and definitely more of a presence of the mother/poet. Since then I have revised the script to incorporate those elements. Musa's mother is more involved, and there is more choreographed movement of the actors on the stage. Rather than presenting an explicit description of the translation process, the staged metaphor suggests possibilities.

Throughout the several years during which I had worked to create the dramatized metaphor, I continually held a keen awareness that I had ventured into a space somewhere between translation studies and my usual territory of Irish studies. Therefore, I continued to seek new metaphors for translation to add to my growing collection. In my early research, I had not come across one which came close to mine in its imagery. Admittedly, I was seeking some sort of validation that my metaphor would, as James St. André insists, "provide . . . fresh insights" (4).

When I began again to research these metaphors, I did discover some intriguing results, most especially in St. André's valuable collection of essays, Thinking through Translation with Metaphors. In Stephanie Roesler's essay, "Yves Bonnefoy's Metaphors on Translation," I discovered the kindred spirits I had been seeking. First Roesler introduces Bonnefoy's "[depiction of] the author he chooses to translate through different images: he is a friend, a neighbour, or a fellow traveler" (qtd. in Roesler 219). Then, as a companion to Bonnefoy's thinking, she points to Henri Meschonnic's description of translation which, he posits, "is not carrying across, but establishing a relationship with another author" (qtd. in Roesler 217). In Roesler's summative observation I found, along with Bonnefoy's and Meschonnic's metaphors, a degree of validation for my own approach: "All these metaphors tell us again that an intimate relationship, a relationship of trust, is established between the source-text author and the translator. . . . They walk together on the path of poetry, and the translator follows the author with respect until ... she is able to find her own path unaided" (qtd. in Roesler 218). In this last sentence, and especially in her use of the female pronoun at that point in

\footnotetext{
10 The word is found in the following quotation from the Qur'an, which references Jesus: "And he shall speak unto
} mankind from the cradle ..." (Qur'an 3:46). 
her article, I heard a description of the relationship I had envisioned and dramatized between Myriam and her/Musa's mother, between a translator and a source-text author.

The Play (In which I walk with the reader through the metaphor as I have created and staged it.)

The play has always begun, in its several versions, with the reading of the Moses story in Hebrew, followed by the Musa story in Arabic, ${ }^{11}$ and a third rendering in English. These readings are heard from off stage; after they finish, a spotlight then opens up on a woman seated stage centre; on the back of the stage is projected an image of a stream running among reeds,

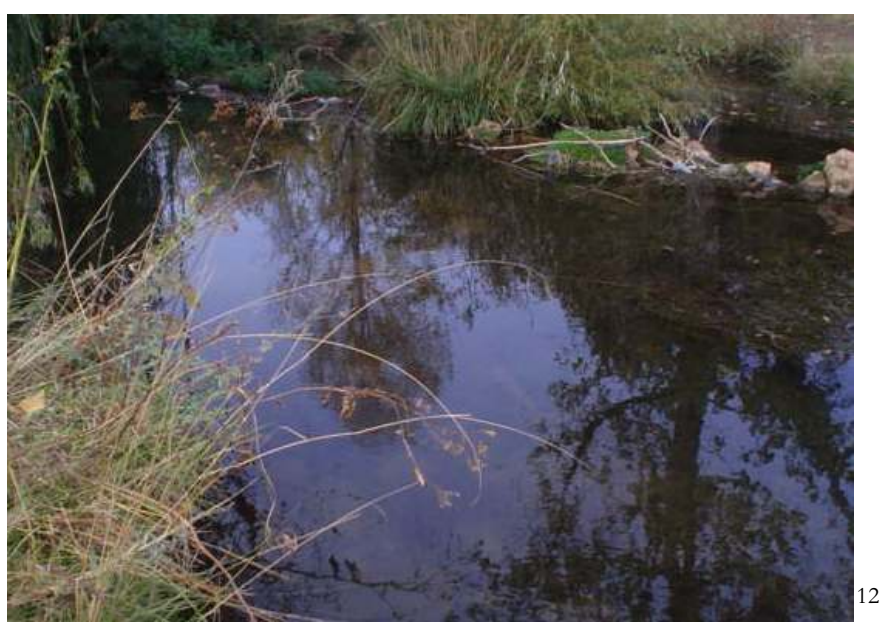

and we hear a voice reading, first in Irish and then in English, "Ceist na Teangan" / "The Language Issue." ${ }^{\prime 3}$ During this reading, first one dancer and then another move around the stage, interpreting the words of the poem, as flute music plays softly.

This use of dance to accompany the reading of the poem is an addition to the original script, a decision I made after reading articles by Kim Wallmach and Leslie Satin, early in the process of creating the chamber theatre script. I was deeply immersed in Ni Dhomhnaill's focus on the "little boat / of the language. .." and was attracted by Wallmach's words, which seemed to complement Ni Dhomhnaill's. Wallmach observes that "The translation process itself can be conceived of as an action in which the movement along the surface of the language is made visible ..." (2). As I saw it, Ni Dhomhnaill's "little boat/of the language" was stretching and morphing to become the river itself, a "surface" on which the heart of the translation process moved and was "made visible." This thoroughly appealed to me; I felt as if Wallmach was inviting me to put my metaphor out there where it could move around and be seen by an audience. This encouragement was complemented by Leslie Satin's article, "The Legs of the Theorist," in which she not only celebrates the use of dance

\footnotetext{
11 This is an audio link to the chanting of Surat Al-Qasas (The Stories), 28: 1-15: http://quran.com/28

12 Photo credit Author

${ }^{13}$ For convenience, the video link is provided again: https://www.youtube.com/watch?v=1c5lxRqzOEA
} 
in an academic context, but also reinforces the basic premise set forth by Espinola, Pelias and Taylor, about performance being a legitimate form of literary criticism. Speaking to the role played by the dancer in the academic world, she observes:

In some instances, dancers have read the feminist or literary or queer theory . . . . But as movers ... we always know - as a process - how movement makes meaning, in ways that are beyond language. I don't know if [the phrase] "the wisdom of the body" is too breathless for academia, but I know that I believe in it and I don't see that belief as signaling . . . the exclusion of intellect. (122)

In the case of my play, with the tale of Moses fresh in the audience's ears, I wanted to use dance, accompanied by only the faintest flute music in order to create "meaning, in [a way] that [was] beyond language." I hoped that dance would allow the audience to join me at the point in my own mind at which I had begun to fashion the metaphor.

On the stage, the dancers are moving: one is the mother, fearful of Pharaoh's order to kill all boys upon their birth; a few dancers become the stream itself, carrying the basket-as-boat as it makes its way "hither and thither" to the Pharaoh's daughter; another is Pharaoh's daughter, coming to sit by the stream; yet another is Myriam, following and watching. As the last words of the poem are spoken: "in the lap, perhaps, / of some Pharaoh's daughter," the lights go down as most of the dancers exit, and come up again on the Pharaoh's daughter, left sitting alone with the infant in the basket. She speaks to the child:

I am the daughter of mighty Pharaoh, and today I have found you in a basket, a floating crib. Hidden among the iris leaves, rustling with awakening, lies your swaddled hope. And so begins my new story, which is the tale of your words and your rbythms, first entrusted to the reeds and the ripples, and now resting in my care. But what am I to do with you? You are from another country, one whose language I do not understand.

It is then that Myriam steps out from hiding and, through dance ${ }^{14}$ and gesture, shows the daughter that she is able to care for the infant/text, and invites the daughter to hand her the basket and come with her. They exit, as the lights dim and then go down. The audience is still holding the story of Moses, including how Myriam retrieved the child and brought him home to his mother, to a space within which he could be nurtured, and could grow into someone ready to be returned to Pharaoh's court. At the heart of this performed metaphor is the bringing of the text to a space within which Myriam-as-translator can work with the author to allow the process of translation-as-relationship to happen, resulting in a new text, now available to a new reader. In the course of the play, the audience will repeatedly see Myriam take charge of a text's transformation, in the close presence of

${ }^{14}$ It is somewhat fitting that Myriam dances throughout the play. There are few references to her in the Bible, but one of them involves a brief mention of her leading the Jewish women in a celebratory dance as Pharaoh's army is swept into the sea: “Then the prophet Myriam, Aaron's sister, took a tambourine in her hand; and all the women went out after her with tambourines and with dancing" (Exodus 15:20). 
the mother/author. ${ }^{15}$ I have clarified, in the program handed to the audience, that this is one metaphor for the process of translation: one possibility, but certainly not the only one. The basic structure of the dramatized metaphor, which we in the audience will see unfold, places choreographed movement and dance on an equal footing with that of the recited texts.

At this point in the play, the lights come up on Myriam, standing centre stage, with a basket in her hands. As the light increases, we notice that the room is furnished simply: a Berber carpet hangs on one wall, and a tajine ${ }^{16}$ sits in the middle of the table. A tall chest of drawers (a "dresser") stands against one wall, with a picture of the Pope resting on the top, alongside a piece of Irish delftware. ${ }^{17}$ At stage left sits a woman, whom we recognize as the mother/author, from the opening dance in which she gave up her infant/text. Myriam moves to the woman, who rises and moves in tandem with Myriam around the stage, and back to the centre. The effect is that of women creating a safe space, spreading the energy of the translator-with-author relationship around the room, within which the translations will take place. Thus the stage is set for the unfolding of the metaphor.

It seems appropriate to mention here that I named the character of the mother Mahida, after discovering the word's connection to "crib/cradle," and considering the twofold nature of the name's meaning. Certainly Musa's mother would have been "one who comforts," given the ways in which she is described in the Old Testament and Qur'anic accounts. Additionally, her role as author, in relationship with Myriam/the translator, connotes "one who makes things even and uniform" or "a facilitator."

After the two women arrive at stage centre, the mother returns to her seat, and Myriam begins to welcome the audience and describe this place: I am Myriam; this is my house. Some days are ordinary: there are socks to be darned and potatoes to be peeled. But on other days, a strange breeze opens my door. My life is visited by the stories of women; they come in many languages and leave in others. On those days, my house is the house of translation. When she finishes, the lights go down again; as they come up, Myriam is seated at the table, stage right, peeling potatoes. We are returned to the everyday life that Myriam has mentioned. What we in the audience see is this:

There is a knock, a slight pause, and a woman enters, cradling a bundle in her arms, and comes to center stage. Myriam puts down the knife and potato and makes a gesture of

\footnotetext{
15 I have taken liberties with the Biblical and Qur'anic narratives here, since nowhere is it explicitly written (only implied) that Myriam actually takes charge in this way. In the Qu'ran, in fact, it is Pharaoh's wife, Asiya, who finds Musa floating in a box in the water. The rest of the story, including the presence of Myriam, is essentially the same.

${ }^{16}$ In this case, the word means a pottery vessel used to cook a variety of stews in North Africa; the word also refers to the stew itself.

17 These items, from both North African and Irish cultures, provide a visual representation of the blending of the two cultures in the readings.
} 
welcome. The woman then reads her text ${ }^{18}$ from a paper hidden in the bundle. She then places the bundle in the basket, incorporating fluid movements and gestures.

In this way, after each woman enters and repeats the process, Myriam rises and, again to soft flute music, takes the bundle out of the "crib;" she then invites the author to walk/dance with her, and the two of them move it around the center of the stage and over past her own mother, pausing to incorporate a bit of that earlier movement and energy, just enough so that the audience is reminded of this character's role in the metaphor and in the process of translation. It reminds us that the author - any author in this case-is possibly a presence in the act of translation, while the translator remains in charge. This mirrors a process described by several translators whom I have interviewed. As an example, Imke Ahlf-Wien speaks of her work with Najem Wali. She says,

I have worked very closely with the Iraqi author Najem Wali (who has lived in Germany for more than 20 years and speaks German very well), when I translated several of his novels from the Arabic. ... I asked him many questions especially in my first two translations and always got an answer. I always felt that he trusted my instinct, my gut-feeling about certain words or formulations. He told me on several occasions that he felt I got the "tone" of his work. ${ }^{19}$ (Interview)

Metaphorically, Myriam/the translator, by maintaining the presence of her mother/the author through gesture and dance during the translation, ensures the continuing presence of her mother/the author in Musa's/the text's future existence at Pharoah's court/in the translated work. Congruently, Bonnefoy "describes the translator as the ... one who ... will assure [that the author remains] a presence in another language and another culture" (qtd. in Roesler 220).

Back in our play, Myriam moves from the presence of the mother/author, back to the basket, signifying the completion of the process of translation, and places the bundle in the basket. As this is happening, each author of each text retreats to the periphery of the stage and sits. Myriam then moves with the basket into the audience, arriving at a different person each time. It is at this point that I incorporated another change from the first performance. I have "planted" several people in the audience as "readers." I did consider using unsuspecting audience members, which may have provided a certain spontaneity, and perhaps more "authenticity." However, I decided to prepare some audience members ahead of time to represent "the reader" of a newly-translated text. My intent is to dramatize the reception of the text in the hands of the reader, and demonstrate the

\footnotetext{
18 Some women bring complete poems, some an excerpt from a poem or from a prose text. Each woman reads the text in its source language: Irish, Arabic, French or Tashelheit.

19 Similarly, speaking as the author of the Moroccan novel The Year of the Elephant, Leila Abouzeid told me that she insisted on working with Barbara Parmenter, who translated the work into English. Imke Alf-Wien, who translated Abouzeid's novel into German, also spoke of Abouzeid's willingness to allow her to use Parmenter's English translation, at times when she was needing a clearer understanding of a particular portion of the Arabic original.
} 
reader's ability to read it in her own language, thanks to the translator. Since this is such a significant element of the metaphor, I wanted to enable each person to "act the part" confidently.

As Myriam places the basket in the lap of each reader, she invites her/him to read the text aloud. The person stands, hands the basket back to Myriam, takes the bundle from the basket, and reads the current text (which is also hidden in the swaddled material) in English. The two then make their way back to Myriam's house, and the reader sits in a seat along the back, at stage right, where Pharaoh's daughter has been sitting silently. After a short pause (with music coming to the fore) there is another knock, and the pattern continues.

The texts brought by the authors do have a common theme, following on from that of my initial readers' theatre piece: in general, they are women who dwell on the margins of their given society, some of them further marginalized by speaking in languages not often heard outside their indigenous localities. I use poems by Biddy Jenkinson, Eithne Strong, Ni Dhomhnaill, and Mhac an tSaoi (Irish), as well as poems from Mririda n-Ayt Attiq (Tachelhit), excerpts from Abouzeid's Year of the Elephant (Arabic), and Mokeddem's The Forbidden Woman (French). Thus, the play becomes more than the dramatization of a metaphor. We in the audience are also exposed to the common themes present in the texts of North African and Irish women, which originate in diverse cultures, written in assorted languages.

To return to our stage, we reach the end of the visits from the women; the translations have danced and flowed from source languages to target ones, in the ever-watchful presence of Musa's mother and the other authors/mothers. On the stage we have the various authors and readers, the latter of whom are, at the end, the caretakers of the texts. The dances of the individual authors/mothers now merge into a poignant leave-taking from the infants/texts and the readers. Myriam's mother leads the other authors in a dance of farewell, as they move to the outer spaces of the stage. There are some spoken lines, in addition to the movement, together expressing that letting go. As they fade into the margins of the stage Pharaoh's daughter returns, and gathers the readers for a final dance. This movement and speech celebrate the new and enriched texts, emerging from the essence of the originals, which still remain, even as Musa remained Musa, as he grew and developed into the court-ready child. The readers' dance is first one of appreciation to Myriam, as the translator, and then a final expression of delight in their ability to read and appreciate their texts. This scene was inspired by Susan Bassnett, who observes that "[t] he discourse of translation has been characterized by emphasis on what is lost, never on what might be gained" ("Traveling" 8). Because I want to help balance that emphasis on the loss, this is a crucial portion of the play, since it brings closure to the process of translation. What the final dance expresses is not only what is gained, but also what remains from the original; the child/text stands as a new being/entity on its own, even as its core being, the essence of the original, is untouched. 
Slowly the lights dim on the readers/dancers, and then completely go down. When they come up, we once again see the woman who has portrayed Pharaoh's daughter, but she is no longer dressed as that character. Rather, she has removed her robe, which signified her royal status, and is sitting, again in front of the photo of the reeds and river, reading a book. Her body language and facial expression convey her involvement with the text; she sits still while the faint flute music plays, and after one minute the lights go off. It is the final impression left with the audience.

\section{Conclusion}

We look once again at Bonnefoy, as explicated by Roesler: "[T]he translator is the one who . . . "brings to maturity some of its still unripe fruits on the boughs"' (225). If we think carefully about that infant/text placed in the basket and sent out into the world, we will recognize that it is Myriam/the translator, in relationship with the mother/author, who "brings to maturity" the infant/text. Musa/the text is a "[fruit] of the original." In the process of ripening/becoming a child, the text/infant has been lost, in a way, to the mother/author, in the return to Pharoah's daughter/a reader, as a more mature being/an accessible text, ready to stand, "translated," in a new culture/with a new reader.

Earlier, I referenced James St. André's insistence on the systematic development of any metaphor for the translation process. When I look back over this process, I contend that I have thus far systematically developed the metaphor, one which indeed provides what Paul Ricoeur calls "some true insight about reality." As for the impetus that led me to develop this metaphor, I note that I built on the foundation laid by Espinola, Pelias and Taylor, which had provided the underpinning for my doctoral work. I also took to heart the caution offered by Marnia Lazreg, and set aside the "privileged explanatory power" associated with my original theme of Éwomen writing in a theocratic society," all the while maintaining the characters and motif of "marginalization" of the readers' theatre script. Beginning with that production, and then through several conference presentations, I have elicited the critical feedback of academic colleagues in the fields of literature, dance, theatre and translation studies. This necessary component of the rather non-traditional nature of performance-as-criticism allowed me to incorporate thoughtful suggestions into several script revisions. In this way I removed some elements to which I had been attached, but which neither unwrapped the metaphor, nor contributed to the story line.

Resonating throughout the process was the significance of what Jacqueline Taylor had named "performance knowledge," which had been reinforced by Leslie Satin's references to "meaning beyond language" and the "wisdom of the body." At one point, I even took issue with what I interpreted as Taylor's betrayal of her own approach. She had maintained that, "in order to make clear the legitimacy of performance as a critical endeavour, we need to supplement this 'felt knowledge' with translations into more conventional forms of critical discourse" (67). 
Having come to a fuller understanding of the process of translation, I now look back at Taylor's words with more appreciation. She called for "translations" of the performance knowledge into "more conventional forms of discourse." If I accept her premise, then it seems I have become a translator of sorts. The process of translating the "felt knowledge" gained from the staging of this metaphor has only begun. 


\section{REFERENCES}

Abouzeid, Leila. Year of the Elephant. Trans. Barbara Parmenter. Austin, TX: Centre for Middle Eastern Studies, 1989.

Ahlf-Wien, Imke. E-mail interview. 8 July 2014.

Attiq, Mririda n-Ayt, and René Euloge. Tassawt Voices. Trans. Michael Peyron. Ifrane, Morocco: AUI Press, 2008.

Bassnett, Susan. Translation Studies: Revised Edition. London: Routledge, 1991. Print.

---. “Traveling Through Translation.” Comparative Critical Studies. 6.1 (2009): 7-19.

Benjamin, Walter. "The Task of the Translator." Walter Benjamin: Selected Writings. Vol. I. 1913-1926. Eds. Marcus Bullock and Michael W. Jennings. Cambridge, MA: The Belknap Press of Harvard UP, 1996.

"Crib." An Etymological Dictionary of the English Language. Ed. Rev. Walter Skeat, Litt. D. New York: Macmillan, 1893. Google Books. Web. 20 Aug. 2009.

“Crib.” Merriam-Webster's Collegiate Dictionary. 11 $1^{\text {th }}$ edition. 2003.

Espinola, Judith. "Oral Interpretation Performance: An Act of Publication." Western Speech Communication 41.2 (1977): 90-97.

"Exodus.” The Holy Bible. New Revised Standard Version. Iowa Falls, IA: World Bible Publishers, 1989

Lazreg, Marnia. "Feminism and Difference: The Perils of Writing as a Woman on Women in Algeria." Feminist Studies. 14.1 (1988): 81-107.

Mhac an tSaoi, Maire. Personal Interview. 18 Mar. 2005.

Mokeddem, Malika. The Forbidden Woman. Trans. K. Melissa Marcus. Lincoln: University of Nebraska Press, 1998. Print.

Moustakas, Clark. Heuristic Research: Design, Methodology, and Applications. Newbury Park, CA: Sage, 1990. 
Ni Dhomhnaill, Nuala. “The Language Issue." Trans. Paul Muldoon. Pharaoh's Daughter. WinstonSalem, NC: Wake Forest University Press, 1993. Print.

---. Personal interview. Mar. 1990.

Pelias, Ronald. "Schools of Interpretation Thought and Performance Criticism." The Southern Communication Journal. 50 (1985): 348-65.

Pratt, Paula. "Even As We Speak: Heuristic Inquiry and the Staging of Contemporary Irish Women's Poetry.” Diss. Union Institute and University, 1992. Print.

---. "Moving on from the Lap of 'some Pharaoh's daughter': Nuala Ni Dhomhnaill's Poem and the Performance of Translated Work." Paper presented at the annual conference of the Canadian Association for Irish Studies, Montreal, Quebec, Canada, July 2011.

Ricoeur, Paul. "The Metaphorical Process as Cognition, Imagination, and Feeling." Critical Inquiry 5.1 (1978): 143-159.

Roesler, Stephanie. “Yves Bonnefoy's Metaphors on Translation.” St. André 211-240. Print.

Schulze, Ingo. "Toast or Corn? Notes I made for This Speech and Then Discarded." Trans. Susan Bernofsky. Review of Contemporary Fiction 24.3 (2004): 74-78.

Satin, Leslie. "The Legs of the Theorist.” Dance Research Journal 43 (2000-2001): 120-24.

St. André, James, ed. Thinking Through Translation with Metaphors. Kinderhook, NY: St. Jerome Publishing, 2011. Print.

---. "Translation and Metaphor: Setting the Terms.” St. André 1-16. Print.

"Surat 28." The Noble Qur'an. Qur'an.com Web. 9 Mar. 2015.

Taylor, Jacqueline. "Documenting Performance Knowledge: Two Narrative Techniques in Grace Paley's Fiction.” The Southern Speech Communication Journal 53 (1987): 65-79.

Wallmach, Kim. "Feminist Translation Strategies: Different or Derived?" Journal of Literary Studies 22. 1 / 2 (2006): 1-26. Web. 28 Feb. 2015. 